Stephanie Decker

\title{
Africanization in British Multinationals in Ghana and Nigeria, 1945-1970
}

\begin{abstract}
Multinationals experienced significant legitimacy challenges in lessdeveloped countries between 1945 and 1970. Corporate responses to these challenges cover three distinct periods. Unsuccessful postwar attempts focusing on colonial welfare concerns were followed by pragmatic endeavors intended to repair corporate reputations by Africanizing senior management. By the 1960s, this had become a common approach to legitimization. The challenges of Africanizing ethnocentric multinationals led to organizational changes: internationally diversified multinationals were better able to decentralize subsidiary management, while the late 1960s saw regionally focused multinationals absorbed by more diversified multinationals. Organizational survival was directly linked to legitimacy advantages derived from Africanization.
\end{abstract}

Keywords: Legitimacy, Africanization, Ghana, Nigeria, Multinationals, History 
The decolonization of European empires in the 1950s and 1960s posed significant challenges to international business, which had to adapt rapidly to the still-evolving institutional environments of newly independent states. The 1960s and 1970s also witnessed a period of significant criticism of global capitalism. The operations of multinational companies (MNCs) came under increased scrutiny. These unprecedented challenges to the organizational legitimacy of international firms have been studied from a variety of perspectives in international business history and imperial history. ${ }^{1}$ In particular, Marcelo Bucheli and his coauthors have analyzed this from the perspective of legitimacy theory, a management theory that has much to offer to business historians. ${ }^{2}$ Bucheli and Kim suggest integrating organizational legitimacy in order to research "how firms choose different legitimization strategies in response to the political process and how these choices interact with changes in the institutional environment over time."3

Legitimacy refers to "a generalized perception or assumption that the actions of an entity are desirable, proper, or appropriate within some socially constructed system of norms, values, beliefs, and definitions." ${ }^{4}$ Existing studies of organizational legitimacy in management and organization studies deal with challenges to legitimacy that are relatively minor compared with historical studies. In particular, cases of complete reversals of institutional legitimacy conditions, such as major regime change, are rarely picked up by scholars, because they tend to focus on contemporary organizations in developed countries over relatively short periods of time. ${ }^{5}$ International business history can offer significant insights into how firms deal with major legitimacy challenges, but it focuses on in-depth historical case studies, with some notable exceptions. ${ }^{6}$ In a 2011 editorial, the editors of this journal called for broad conceptual generalizations and greater engagement with approaches from other social sciences. ${ }^{7}$ For international business history research in developing countries this is particularly relevant, as the field has grown significantly in the last decade with individual company or country case studies in Africa, Asia, the Middle East, and Latin America. ${ }^{8}$ Integrative approaches to international business history exist, but often take the form of a collection of individual case studies clustered around a theme, rather than a synthesis of cases. ${ }^{9}$ The development of a broad, integrative framework would enable historical researchers to compare and contrast different regions and individual cases, to expand our knowledge of the evolution of MNCs in developing countries. For example, historical cases could demonstrate how similar strategies lead to different results in different national settings, as well as show evidence of the diffusion of successful strategies within MNCs. The purpose of this article is to offer a new approach to thinking about strategic change in MNCs in terms of organizational legitimacy theory. 
By focusing on researching British multinationals in Ghana (formerly the Gold Coast) and Nigeria from a comparative perspective, this article seeks to highlight the evolution of legitimization strategies within their historical context, both at a national and an international level, and the impact these strategies had on the internal organization of MNCs, particularly in terms of staffing. Africanization became an important legitimization strategy between 1945 and 1970. Legitimization strategies are defined as concerted and persistent organizational actions aimed at gaining, maintaining, or repairing organizational legitimacy. From the late 1960s and particularly the 1970s onward, Africanization was also used to refer to the expropriation of foreign firms, but in the context of this study it refers to the recruitment and promotion of African staff within public and private organizations. While historical research on MNCs in developing countries has highlighted that hiring and promoting more domestic staff was pervasive after 1945, few studies seek to conceptualize it as a strategic response, or to consider how MNCs comprehended it on an organizational and international level.

\section{Legitimacy Theory in Historical Research}

Organizational legitimacy was initially described as a resource somewhat outside the control of organizations and not necessarily "conferred by a large segment of society." 10 Suchman's definition of legitimacy as a generalized perception that the activities of organizations are appropriate and desirable in the context of social norms and values is the most widely accepted, and the most suitable for historical research. ${ }^{11}$ Legitimacy "is dependent on a history of events." 12 Major transitions in the institutional environment are likely to affect the way in which organizations and organizational practices are judged in terms of their legitimacy.

Suchman's definition incorporates different types of legitimacy, specifically pragmatic, moral, and cognitive approaches. ${ }^{13}$ Pragmatic legitimization essentially overlaps with strategic conceptions of legitimacy, which emphasize the ability of organizations to manage this resource effectively. Focused on an organization's most immediate audiences and their selfinterested motivations, this can take the form of monetary or nonmonetary exchanges, or of support for projects or policies. ${ }^{14}$ Moral value judgments about an organization are based on a wider audience's value system and reflect beliefs about promoting social welfare. ${ }^{15}$ Companies can still strategically manage aspects of this type of legitimacy by making self-serving claims, or through practices such as window-dressing or greenwashing. Finally, cognitive legitimacy 
is the hardest type to manage strategically. For example, during the Cold War two different economic ideologies considered different types of organization legitimate: private companies in the "West" and state-owned enterprises in the "Eastern Bloc." Cognitive legitimacy essentially refers to the forms and standards that are taken for granted by a group of people. ${ }^{16}$ It can be difficult to establish whether cognitive legitimacy can be maintained, especially in highly volatile institutional environments.

Organizational legitimacy presents different types of challenges: gaining, maintaining, and repairing legitimacy. While gaining legitimacy is an entrepreneurial concern relevant to the creation of new industry, distinct challenges are faced when maintaining and repairing legitimacy. However, in terms of repairing legitimacy, management strategies are much more limited than those for gaining or maintaining legitimacy. I highlight the different periods in terms of legitimization strategies below (table 1) and categorize the challenges as attempts to either repair or maintain legitimacy (whether successful or not).

\section{[Table 1 about here]}

Legitimacy challenges usually emanate from wider societal changes; the most dramatic shifts in organizational legitimacy are cases of sudden regime change, such as military coups, but there are also more gradual ones arising from the transition from colonialism to independence. ${ }^{17}$ For former colonies in Africa and elsewhere, decolonization and the aftermath of independence can be described as a period of "postcolonial transition," when institutional arrangements were in a state of flux and required firms to adapt very quickly to new political, social, and economic contexts. ${ }^{18}$ Hence, historical case studies of legitimacy challenges can offer significant insights into how firms manage to repair or maintain their "license to operate." What is deemed legitimate is clearly temporally bounded, requiring companies to continuously maintain legitimacy. In international business history, there are many cases that can be interpreted as a loss of organizational legitimacy, for example, expropriations or significant regulatory changes that undermine existing business models. ${ }^{19}$ Multinationals in Ghana and Nigeria faced expropriations in the 1970s, which highlights that strategies to maintain cognitive legitimacy were only partially successful in the long term.

Research on multinationals is particularly relevant in this context, because multinationals are embedded in multiple institutional frameworks, which makes managing legitimacy significantly more complex. ${ }^{20}$ Different audiences may evaluate an organization's 
attempts at maintaining or repairing legitimacy differently, and the relative importance of these audiences may change rapidly. ${ }^{21}$

\section{Methodology}

The companies selected for this study reflect a range of sectors relevant to West African economies at the time (trade, banking, and mining) and were among the biggest firms operating in terms of revenue and employment. When the Nigerian government consulted with eight business representatives in 1951, four of the five companies chosen for this study-Bank of British West Africa, Barclays Bank DCO, the Unilever subsidiary United Africa Company (UAC), and John Holt \& Co. (Liverpool)—were involved. The fifth company, Ashanti Goldfields Corporation (AGC), only operated in Ghana and was one of its largest companies. The selection was also partially determined by the accessibility of archival deposits of sufficient quality, although there is some unevenness in coverage between the different firms. ${ }^{22}$ Records from companies that maintain internal organizational archives are usually of higher quality and cover longer periods. Since the 1960s, those companies that either have ceased to exist or have been merged (and in two cases demerged) have deposited their files in public archives. Apart from AGC, these archival collections were less comprehensive than their internally curated counterparts and more uneven in their coverage.

The documents consulted were not digitized and consisted mostly of social sources such as letters, meeting reports, photographs, and employee and salary lists that were created as part of normal organizational routines. There were also some narrative sources, such as memoirs, diaries, drafts for corporate histories, and transcribed oral histories, which represented on the one hand a degree of reflection about historical events, and on the other an attempt to frame past events in terms of present necessity. ${ }^{23}$ Staffing issues emerged as a key concern for MNC managers and were explored for all five companies.

\section{[Table 2 about here]}

The MNCs in this study show distinct features in terms of their locational choices. Several originated as freestanding companies or regionally specialized MNCs. ${ }^{24}$ Barclays Bank DCO was formed in 1925 through a merger of the Colonial Bank with other regionally based overseas banks. ${ }^{25} \mathrm{UAC}$ also had its origins in a merger, becoming a wholly owned subsidiary 
of Unilever in 1929, with operations mainly in West and Central Africa, but also having a large U.K.-based head office. Like Barclays, UAC benefited from its links to its parent company, and due to their significant global branch networks, both companies are classified as internationally diversified MNCs.

Other British MNCs operating in West Africa did not have the same international scope. The Bank of British West Africa, renamed the Bank of West Africa (BWA) in 1957, was founded in the late nineteenth century as a regional bank for the British West African colonies and continued to focus its operations there. The same was true for the Liverpool-based John Holt \& Co. (Holt), which began as a trading company operating in Nigeria and later expanded to the Gold Coast, operating its own fleet of ships. Finally, AGC operated a gold mine in Obuasi, the Gold Coast, and had its head office in London. These regionally focused MNCs were not managed as a geographically diversified network of multinational subsidiaries like Barclays or UAC.

For the regional MNCs, archival resources are uneven compared to those of the internationally diversified MNCs. Holt's files were deposited across different archives and vary in coverage and quality. The BWA's files for the 1940s to the early 1960s are in the London Metropolitan Archives. The narrative only refers to these two companies where information was available. For AGC, the archival deposits were rich and detailed. Additional archival and secondary sources were used where appropriate, such as the Bank of England Archive and colonial and commission reports, as well as a limited number of interviews with current and former employees.

\section{Losing Moral Legitimacy}

British business in the British Empire maintained relatively good connections with both the Colonial Office in London and the colonial governments. The creation of commodity marketing boards, especially during World War II, and attempts to form a cartel of merchants (mainly British but also some French and Swiss companies) were controversial strategies to control colonial economies, though their effectiveness was often limited. ${ }^{26}$ In this imperial context, the challenges faced by domestic businesspeople in gaining recognition as legitimate commercial organizations by the colonial government were greater than those of foreign European interests. This highlighted a significant disjunction in terms of West African societies' and colonial governments' legitimacy judgments. An example of this tension is the 
Kojo Thompson case of 1944, in which a Gold Coast lawyer was accused of impropriety by a British businessman. This case clearly split public opinion along colonial lines. ${ }^{27}$

In the 1940s, the increased importance of the empire's war effort led to a brief resurgence of an imperial sense of mission. ${ }^{28}$ The 1940 Colonial Development and Welfare Act shifted the focus toward development, progress, and better living standards as the new basis of colonial legitimization. The political objectives of development were clear: to maintain the acquiescence of colonial subjects in the British Empire, and to increase the empire's economic value. However, this strategy backfired as colonial administrators became embroiled in a wave of public and labor unrest, which eventually made the passing of control to African elites more acceptable to metropolitan audiences. ${ }^{29}$ These momentous changes undermined the previous basis of legitimacy for British imperial firms in the Gold Coast and Nigeria; in fact, their perceived association with colonial governments became a source of embarrassment to the Colonial Office. British companies slowly became aware of the need to actively manage the impact that rapid institutional changes were having on them.

While these changes affected practically all aspects of commercial life, it was the employment of West Africans that was among the most controversial and that saw the most significant change over time. Both public and private organizations, such as the Colonial Office and imperial businesses, began to conceive of labor as a crucial resource that needed to be managed scientifically. This notion became increasingly influential in the debates on colonial development, especially as fears grew that workers could be mobilized to protest by trade unions and Communist groups.

For the Colonial Office in London, which oversaw the colonial governments in the Gold Coast and Nigeria, the continued right to govern these territories was increasingly predicated on the idea that the British Empire furthered the economic development and social welfare of the territories and people under their authority. Development and welfare were two concerns that were linguistically and symbolically linked in the Colonial Development and Welfare (CD\&W) Act in 1940 and clearly endorsed by the Colonial Office in 1945: "Social welfare and economic prosperity cannot be separated. Good health, good houses, good food, good water - these are the elements of social welfare and they cannot be had except on the basis of a sound and stable economic system." 30

In practice, much of the welfare debate focused on labor and was defined as the application of "new techniques ... which were worked out more recently in 'advanced' countries," either because domestic responses did not exist for coping with the changes brought about by economic development, or because industrialization and the growth of cities 
undermined them. ${ }^{31}$ This meant that, on the one hand, the need for welfare arose as a result of economic development and was supposed to ameliorate the social disruption that economic growth caused. On the other hand, welfare measures were seen by both colonial officials and business as a paternalistic tool to improve worker productivity. ${ }^{32}$

In Cooper's analysis of colonial labor policies during decolonization, the colonial governments' attempts to curb labor discontent failed. This created opportunities for nationalist politicians to highlight that they were necessary partners for any economic, social, or political transition, ultimately hastening the process of decolonization. Between 1948 and 1951 a number of consumer protests, riots, and strikes swept through West Africa. This unrest was successfully co-opted by nationalist politicians in both the Gold Coast and Nigeria, and by the early 1950s the transfer of power to nationalist politicians was underway. To date there has been little research into how this affected private companies, especially British firms so closely associated with the empire that they were commonly considered "imperial business."

\section{Corporate Responses to Politically Motivated Strikes, 1945-1952}

Foreign multinationals - and, due to their home nation, British firms in particularnow had to legitimize their continued presence in terms of their ability to contribute to social and political developments as an early form of corporate social responsibility. However, this turned out to be a heavily politicized basis for organizational legitimacy, as strikes, demonstrations, and riots challenged the postwar colonial order in the late 1940s. By the early 1950s, the failure of these attempts was widely acknowledged and demands for social and economic advancement were eclipsed by increasingly rapid constitutional evolution leading ultimately to political independence. For British businesses operating in the Gold Coast and Nigeria, it became paramount to repair their organizational legitimacy, as they had no intention of leaving with the British Empire, which had essentially guaranteed their "license to operate." Unless companies could convince the new African elites that they remained legitimate forms of organization in a fundamentally changed institutional environment, their future appeared to be in question, as Holt's district agent in Lagos, G. Cotgreave, noted in 1949:

A number of political speeches were made, stressing the need for executive powers being given so that they could ensure that the trade of Nigeria was enjoyed by Nigerians and not by the few big firms. I was surprised at this attitude, which was most unexpected, but it is a pointer of how some of our possible future legislators are thinking. ${ }^{33}$ 
British businessmen found their companies embroiled in "political strikes," which were not about workplace issues, and hence offered no basis for negotiation between management and unions. African nationalists benefited greatly, either by leading the unrest against the political establishment (like Kwame Nkrumah in the Gold Coast in the Positive Action campaign), or by resolving an impasse in negotiations (like the National Emergency Committee in Nigeria, an all-party grouping of nationalists, during a major strike in 1950).

For British companies, this early transition phase presented several conundrums. Frederick Pedler, director of UAC, interpreted this as a time when the companies became embroiled in a dispute between nationalists such as Nkrumah (Gold Coast), Azikiwe (Nigeria), and Eze (a trade union leader in UAC's Nigerian subsidiary) and the colonial governments to which they were not really a party. ${ }^{34}$ British companies' close identification with the British Empire, an advantage in terms of legitimacy in earlier decades when imperial rule was not effectively challenged, now made them targets for political demonstrations. This occurred at a time when colonial governments increasingly sought to distance themselves from companies, a decision that British businessmen noted with confusion and disappointment, according to Stockwell. ${ }^{35}$ Her argument has been challenged by Uche, who considered that the relationship between the British government and business remained close. ${ }^{36}$ However, most of the evidence marshaled by Uche refers to the 1970s, when competition for investment among Western powers had changed government policies toward greater investment support. ${ }^{37}$ In the $1950 \mathrm{~s}$, the previously close alignment of official and corporate interests unraveled for a time, as the British government prioritized political disengagement and the maintenance of future diplomatic relationships. At the same time that companies' former political strategies were losing their effectiveness, they were becoming targets of politically motivated challenges.

Responses varied between firms in different industries, but also reflected how closely management identified with the imperial project. A somewhat paternalistic focus on welfare, rhetorically linked to colonial development efforts, was common. A good example of a deeply imperial corporate response is the case of AGC, the major gold mining company in the Gold Coast. From 1945 its operations were overseen by its chairman, Edward Spears, who had connections to the U.K.'s Conservative Party and the Colonial Office. The colonial government took an interest in the working and living conditions in mining communities, especially since the smooth production of foreign exchange-earning commodities was high on the agenda of postwar British economic policy. After decades of relative neglect, in 1946 the Colonial Office changed its policy toward a more active and invasive approach. ${ }^{38}$ 
The Labour government had nationalized mines in the United Kingdom; hence, firms such as AGC faced multiple threats to their legitimacy. AGC found that its labor conditions compared unfavorably to those of other mining companies in the Gold Coast. ${ }^{39}$ The company also managed a large African workforce with a small number of European supervisors - in 1945, AGC employed 6,693 Africans and 111 Europeans, and supervisors were outnumbered 83 to $1 .{ }^{40}$ The prospect of strikes and industrial unrest was deeply threatening, and in combination these two trends led Spears to implement a paternalistic welfare model in response to the first strike he faced, in $1945 .{ }^{41}$ Spears anticipated that increased welfare provision would limit industrial action and improve organizational commitment: "If the Corporation demands loyalty under my Chairmanship in my view the Corporation must be loyal in return to all employees. Protect them and develop schemes which will make for their welfare."42

This new focus on welfare, education, health, and nutrition mirrored official policies that were enacted as part of a wider framework of reasserting imperial control. As a result, however, AGC faced problems akin to those of the colonial governments, because workers appropriated this new framework and turned it into the basis for entitlements. ${ }^{43}$ The complexity of social and economic life in West Africa defeated the mine's attempts at imposing an allencompassing welfare system that was intended to channel industrial participation in ways most convenient for the mine. ${ }^{44}$ Eventually, both Spears and the colonial government had to accept that the economic dislocations of war and the new possibilities offered by the development discourse had culminated in a complex challenge to the colonial order through an unstable coalition of nationalist politicians, organized labor, urban traders, and consumers.

The role of nationalists in cases of industrial unrest was an area that British companies found hard to gauge. The first appearance of Kwame Nkrumah in Unilever's board papers emphasizes how closely his initial rise from obscurity was linked to industrial action in the eyes of British companies: "His method of operation appeared to be to foment strikes with the object of attracting support towards himself." ${ }^{45}$ Nkrumah's Positive Action campaign in 1950 affected most employers on the Gold Coast.

The aftermath of Positive Action campaigns posed further problems for labor relations, affecting trading companies such as Holt and UAC, with their widespread network of branches and large number of dispersed employees, more severely. Their employees went on strike not due to work-related grievances, but rather for political reasons; they had not targeted their employers, but the government. Patrick Fitzgerald, a director of UAC in Accra, pointed out, "The commercial employees admitted that they had no complaint against their employers and that in fact there was no trade dispute." 46 
By spring 1951 the colonial government had negotiated with Ghanaian nationalists, agreeing that civil servants dismissed during the Positive Action campaign would be reinstated. The official negotiator asked the mercantile firms to make a similar statement. Fitzgerald, who represented not only UAC but also the Accra Chamber of Commerce, replied that the case of the firms was different because positions had been filled and no supernumerary posts would be created. His superiors in London suggested saying that the embargo on the reemployment of dismissed workers was lifted and if all other things were equal they would be given preference. Fitzgerald opposed this, stating, "This will have a particularly bad effect on local staff and I shall be severely attacked by our Union who have not time for those who abandoned their employment." $" 47$

This underlined the political nature of the 1950 strike and problematic lines of conflict between companies, trade unions, African politicians, and the colonial government. When a motion to reinstate workers dismissed during the Positive Action campaign was lodged in the Assembly, its supporters used it "as a stick to beat the Government and we had the very interesting result of Government supporters coming out, diffidently perhaps, on the side of the Firms," commented J. A. R. Williams, Holt's district agent in Accra. The Gold Coast government was vulnerable to nationalist labor politics both as colonial rulers and as the largest employer in the country. While officials feared being seen as closely allied to private business, the complexity of political and social issues made both British officials and companies vulnerable to anticolonial attacks. This undermined their legitimacy at a moral level and offered few potential solutions for compromise. More challengingly, this meant that companies' ability to independently negotiate and resolve issues with their workforce was affected by a political process over which they had little control.

As it became clear that the United Kingdom could not afford to develop its colonial estates, and that promises of development had not made them any easier to control, the end of British imperial rule could be more easily imagined. ${ }^{48}$ In the early to mid-1950s, decolonization became increasingly framed as an issue of constitutional devolution, while development became the area of economic specialists. As development was depoliticized and economics took a back seat in the process of decolonization, nationalists gained access to political power in return. For British multinationals, this posed new legitimacy challenges, as welfare and imperial political associations were fast becoming liabilities, while their position as foreign organizations in control of colonial economies was becoming increasingly controversial. Their attempts to share in the moral justification of the initial postwar imperial resurgence had 
faltered, and as the political and economic realities around them changed rapidly, they had to reconsider their strategies.

\section{Repairing Pragmatic Legitimacy}

The effective repair of foreign companies' legitimacy required a significant reorientation from previous failed attempts. The basing of legitimacy claims on moral grounds through firms' contribution to the social and economic development of the British Empire had not connected with domestic African audiences. This was not only the result of imperialism rapidly becoming perceived as morally reprehensible after World War II, but also because colonial officials were focusing on political devolution and were distancing themselves from British firms, thus further undermining their institutional legitimacy. ${ }^{49}$ As Cooper demonstrated, the promotion of imperial development became socially and politically explosive. In 1956, Hodgkin argued that "African nationalism, like other nationalisms, is in part a revolt against an inferior economic status." ${ }^{50}$ However, this link began to be dismantled from the early 1950s onward, because the focus shifted toward political devolution. Ghana gained internal self-government with the implementation of the new constitution in 1954 and became fully independent in 1957, the first sub-Saharan African country to be fully decolonized. Nigeria followed suit in 1960 in the form of an independent federal state with significant devolution granted to the three major regions. ${ }^{51}$ The removal of economic issues from decolonization and the depoliticization of development offered new opportunities for firms to justify their continued presence in Ghana and Nigeria and eventually facilitated their extrication from the old attempts at legitimization, such as ensuring workers' welfare, which were ineffective in neutralizing escalating demands and political strikes.

Colonial governments began to separate issues of economic and constitutional development in response to the social unrest in West Africa from 1948 to 1951. In the aftermath of the Gold Coast riots of 1948, the Iva Valley miners' strike and massacre at Enugu Colliery in Nigeria in 1949, and the Positive Action campaign in the Gold Coast in 1949 and 1950, the potential dangers of merging economic grievances with political aspirations were apparent to colonial governments. They responded by accelerating political devolution, as well as committing to economic development, to quieten colonial consumers and workers. ${ }^{52}$ In both 
countries, nationalist politicians were co-opted into colonial governments as part of the decolonization process.

By giving local politicians limited internal self-government, political advancement became an issue of decolonization, whereas social and economic progress became the remit of development experts. This was organizationally underpinned by the expansion of the national (and, in Nigeria, regional) administrations, making political reform the subject of political decision making between nationalist politicians and Colonial Office executives, while economic development was left to technical staff and economic experts. Nationalists began to prioritize industrialization and Africanization, in order to ensure greater local autonomy. Throughout the 1950s, foreign companies developed networks with African politicians and businesspeople, and they began to understand that the development and promotion of African staff sent a powerful signal that they were indeed sympathetic to the aspirations of new nations. Africanization turned out to be a more effective legitimization strategy, although tokenism and window-dressing were common, especially in the early stages.

\section{Africanization as a Pragmatic Legitimization Strategy}

For African nationalists, the failure to promote more qualified Africans in business and the civil service was a longstanding grievance. In 1943, the Nigerian nationalist Nnamdi Azikiwe raised the issue with one of Unilever's visiting directors, Frederick Pedler. ${ }^{53}$ Throughout the 1950s, nationalist politicians gained in influence buoyed by a mostly urban, relatively young, and often only partially educated constituency. ${ }^{54}$ This went along with a shift in development thinking from welfare provision for an undifferentiated workforce toward a policy of African advancement that facilitated individual careers in both the public and private sectors.

These fundamental changes in the environment demanded profound changes in the international strategy of multinationals. Perlmutter described this new strategy for subsidiary management and international staff as polycentric in the late 1960s, when the global impact of these changes became more apparent. ${ }^{55}$ Clearly, international strategy was not overhauled because of political devolution in West African economies; rather, Ghana and Nigeria were representative of decolonization in the British Empire and its impact on international business. Polycentric approaches were to some extent already in operation in North American and European subsidiaries, but now they became more common and more geographically wide 
ranging. Polycentric strategies decentralized more decision making to the subsidiaries and aimed to have each subsidiary largely under a host-country management team. This contrasted with ethnocentric approaches, in which home-country nationals ran subsidiaries. However, international business was slow to implement polycentric approaches and lagged behind civil service Africanization. The adoption of Africanization appeared more pragmatic than strategic at this stage, simply mirroring the political sphere in order to appease public opinion.

In the civil service, Africanization became official policy in 1947 with the Harragin report, which mandated the replacement of expatriates "as soon as suitable African candidates can be found." 56 The importance of corporate Africanization for West Africa's development was already emphasized by officials in 1944: "The management of London companies will make it part of their policy to give ... Africans the opportunity of gaining an insight into the proper running of a modern business thus qualifying themselves to take a share in the administrative organisation on the higher levels." $" 57$

In the early 1950 s, only 10 to 20 percent of civil servants in the civil service of the Gold Coast and Nigeria were African. While the data is patchy, it is clear that Africanization gathered speed from the mid-1950s onward, reaching nearly 100 percent in Ghana in 1962 and around 75 percent in Nigeria in 1961. In contrast to previous official policies on social development and welfare, Africanization was a policy aligned with nationalist politicians and the African electorate, as well as with the British government's decision to devolve political authority and deliver independence. ${ }^{58}$

Companies accepted these ideas in principle, and they related their own efforts to that of the government. Richard Dyson, a general manager at Barclays, remarked in 1952 that "the speed with which Africanization is proceeding in the political field is bound to have its repercussions in other spheres including our own." ${ }^{59}$ Firms realized that this not only was necessary, but also created a positive impression with their staff and customers.

As companies began to promote more African staff, several constraints emerged, which were frequently rehearsed as an explanation for slow progress. Qualified staff were scarce and highly sought after, including Europeans who were needed for the expansion of training. Even though education and training were seen as the key to solve these supply problems, they were also long-term solutions when the political environment demanded rapid change. As noted in the Colonial Office's annual report for 1953, “The staff position continued to cause anxiety and to provide one of the chief impediments to rapid development. Full employment in Great Britain has inevitably reduced the field of recruitment, while the flow of fully qualified Nigerians is still only a trickle." 60 
The Foot Commission, which investigated the Africanization of the Nigerian civil service in 1948, considered the extension of secondary education as the long-term solution, together with training and accelerated promotion of existing junior civil servants as short-term measures. Colonial expenditure on education increased more than tenfold in just over a decade. ${ }^{61}$ In both Nigeria and the Gold Coast, qualified personnel were rare, although education was generally perceived to be more widespread and better in the Gold Coast than in Nigeria. ${ }^{62}$ In 1950, literacy in the Gold Coast was estimated at 19 to 23 percent, compared with 10 to 15 percent in Nigeria. By 1970, literacy had risen to 43 percent for Ghanaian men and 17 percent for Ghanaian women; in Nigeria, it was 31 percent and 10 percent, respectively. ${ }^{63}$

The educational background needed for commercial and government employment was rarer still. The Harragin report commented on these problems: "West Africa is still at the stage when an extra bonus has to be paid for an education little higher than literacy." 64 Hence the government accepted that it had to pay more for capable clerks, making the civil service even more attractive for aspiring graduates. ${ }^{65}$ Moreover, public and private employers competed for the available graduates. In 1959, J. B. Loynes from the Bank of England commented on the challenges facing the two British banks in Nigeria:

The steady efflux of white officials from the regional administration had caused regional governments to offer attractive terms, including scholarships in the UK, to Africans. This had led to a serious drain on the promising African staff of Barclays DCO, doubtless BWA as well, at a time when the Bank needed to be at full strength to cope with its rapid expansion. The resignation of Africans had forced the Bank to import more European staff involving substantial outlays on housing etc. ${ }^{66}$

Barclays' managers highlighted this issue from the late 1940s onward, noting that recruits first went into the more prestigious and apparently better-paid government service, then to UAC, and only then considered the banks. ${ }^{67} \mathrm{UAC}$ was also affected, as they noted that "strong competition for the services of educated men and women [exists]. Working for Government carries attractions of prestige which can compete with those offered by private employers." 68 While precise and comparable figures are extremely difficult to obtain, the situation in Ghana and in Nigeria was similar, with the civil service rapidly overtaking UAC as the most Africanized major employer in the early 1950s (see Figures 1 and 2). Ghana was slightly ahead of Nigeria in the process, but in Nigeria the debate soon began to focus on regional and not just federal administration. 
[Figure 1 about here]

[Figure 2 about here]

Even at UAC, Africanization levels barely seemed to increase throughout the early 1950s, but as most companies were expanding at the time due to a commodity boom and strong economic growth, progress was not as stagnant as it appears. Other companies also sought to hire more Africans, but for the banks and AGC only partial figures are available for the 1960s, when firms focused more decisively on developing African staff.

In addition to these constraints, prejudice against Africans in senior positions played a large part in slow progress. British managers did not trust Africans, discouraged their advancement, and tended to use rivalry between African employees as a justification for the slow progress. For example, Frederic Seebohm, who later became the chairman of Barclays, commented in 1954, "It is very difficult for a European to assess the character and ability of an African." 69 The British notion of "character" was culturally specific, and the types of institutions that trained such employees produced insufficient numbers of graduates. This was a problem for commercial firms, as a 1948 circular from Holt underlines: "The best of the products of Yaba, Achimota, and King's College Lagos, are going into Government Service. If our policy in regard to the appointment of Africans to the Managerial grades is to bear fruit, it is essential that our service should be no less attractive than the Colonial Governments."70

Africanization was a pragmatic response to the pressures at the time: full employment in the U.K. meant that expatriates were increasingly difficult to recruit, especially since West Africa ranked low in terms of desirability for an overseas posting. Politically, the companies had to be seen to at least be trying to Africanize, even though their efforts were rapidly outpaced by the Africanization of the civil service in both Nigeria and Ghana. However, the intense competition for qualified candidates and the limited education opportunities available at the time provided convenient excuses for the slower progress. The positive reactions to the appointment of Africans, highlighted that Africanization was an effective and pragmatic response to the legitimacy challenges of formerly imperial companies in rapidly decolonizing countries.

Maintaining Cognitive Legitimacy 
As decolonization accelerated, British multinationals were repairing the damage to their legitimacy by pragmatically following the lead of the civil service. While initially this took the form of token gestures, by the time independence arrived, Africanization was becoming a taken-for-granted strategy, suggesting that the basis for legitimacy was changing from pragmatic to cognitive. In 1961, Chief Festus Okotie-Eboh, Nigeria's federal minister of finance, argued that "the policy of the Federal Government can best be summed up as to Nigerianise rather than to Nationalise." 71 Africanization constituted a clearly visible policy that allowed multinationals to demonstrate that they were in line with the expectations of host governments. Opposition politicians nevertheless challenged some of the underlying assumptions: "The Minister of Finance advocates Nigerianisation and not nationalisation. . . . Does he think that by merely Nigerianising the staff of some of these basic industries then automatically those industries will become Nigerian companies?"72 Despite these disputes, for most of the 1960s Africanization provided an important defense against demands to nationalize foreign companies, even if, in practice, companies fell short of public expectations.

From the multinationals' perspective, demands for more Africanization fitted well with polycentric management strategies, which offered significant legitimacy advantages to business in decolonizing host countries. This process gathered pace in the 1960s and became the new norm rather than an exceptional gesture. Diversified multinationals seemed significantly better at adapting to these new requirements for institutional legitimacy than did regional multinationals. Polycentric strategies were obviously problematic for firms whose logic of operation was inherently ethnocentric.

The decade following independence in Ghana (1957) and Nigeria (1960) saw an end to the commodity boom that had fueled significant economic and political changes. Africanization continued, but it was becoming obvious that the process did not reform existing colonial salary structures. By the 1960s, more qualified Ghanaians and Nigerians were available due to the expanded educational provision, while economic growth was slowing.

\section{Polycentric Management and Africanization}

In the 1950s, the pace of expatriate replacement had been determined by both political pressure and the limited number of qualified Africans. By the 1960s the expansion of education and the economic slowdown were beginning to change things. With the civil service almost fully Africanized, British business now faced increasing pressure to replace Europeans through 
measures such as expatriate immigration quotas. Expatriates now perceived their appointment as temporary and not semipermanent as before. ${ }^{73}$

By 1965 even highly resistant directors like Spears realized that Africanization was unavoidable. Internal figures show, however, that AGC lagged significantly behind its projections for increasing African personnel. In 1962, 9.5 percent of personnel at AGC were African, rising to 39.7 percent in $1966 .{ }^{74}$ These figures only refer to personnel who were monthly paid and office-based, as opposed to miners. Companies like AGC were becoming more concerned about their progress, suggesting that Africanization now formed the basis for cognitive legitimacy.

For Barclays, the figures mostly focus on staff in general, including clerks and messengers. The Africanization of senior staff progressed more slowly, and data on this is sparse. Barclays employed a relatively low percentage of European staff overall —in 1960 in Nigeria it was only 15.7 percent, dropping to 5 percent in 1970, while in Ghana it fell from 7.5 percent in 1966 to 5.6 percent in 1970. However, for managerial and senior staff the situation was reversed: in 1952 only 17 percent of these in Nigeria were African, and no further figures indicating the percentage for Ghana or progress over time could be found. ${ }^{75}$ No information on this remained for Holt or BWA; however, disparate archival sources indicate a hierarchy of desirable employers in this time period: government administration, then UAC and trading companies such as Holt, which offered better employment packages than the banks (Barclays and BWA). Mining companies such as AGC lagged behind the banks. ${ }^{76}$ Throughout the $1950 \mathrm{~s}$, hiring policies were criticized as window-dressing, focusing on high-profile appointments. However, when Barclays appointed its first-ever African manager of a Barclays' branchRobert Mensah in Ghana - as a local director in 1965, it was surprised at the positive reaction from its staff, because Mensah was seen as a substantive appointment. ${ }^{77}$

The recruitment and retention of talented staff remained an issue into the 1960s. Barclays routinely overstaffed in order to overcome potential shortages and increased the minimum salary for its higher-grade staff. In 1961, its Nigerian branches engaged 240 persons, an increase of 16.8 percent. From March to May alone, when most school leavers looked for jobs, staff figures rose by 7.9 percent, but during the same quarter, eighty experienced clerks left the bank (5.6 percent of the total). ${ }^{78}$ BWA's management was similarly aware of this problem. However, its staff policy received a boost after the takeover by Standard, and from 1965-1966 onward it responded to pressure for Africanization by asking ministers or Central Bank governors to release promising employees on the condition that they would be fasttracked in the bank. ${ }^{79}$ This suggests that more diversified multinationals like Standard Bank 
had more experience in addressing legitimacy challenges and recognized the need for goodwill gestures. UAC identified three key areas in which to progress their Africanization in the late 1960s: recruitment (including over-recruitment), not just in Africa but also in the United Kingdom and the United States, where Africans were studying; ongoing training and development within the company; and a focus on retaining talented staff. ${ }^{80}$ In 1968, UAC reported that of its roughly 4,240 management and supervisory staff, 3,080 were African (73 percent). About half of the remaining 1,160 Europeans were identified as technical specialists. $^{81}$

Africanization of staff was not limited to former West African colonies, and polycentric international management became widespread in major multinationals, especially if they were highly geographically diversified with a presence in former colonies. Companies such as Unilever were witnessing similar processes in different subsidiaries, which Unilever's managers cumulatively referred to as "ization":

The next stage which is to bring locally employed managers into the very highest positions in our business it becomes even more important that they should be "Unilever" men in the true sense and not merely good local operators ... our task is not only, e.g. to Indianize our business in India but we must also Unileverize the Indians who have positions of authority in that business. ${ }^{82}$

While Perlmutter singled out Unilever as a company that had advanced from polycentric to geocentric management models, for the 1960s (when Perlmutter made the argument) that was not really the case. Geocentric models seek to circulate staff internationally and appoint the most talented managers regardless of nationality. While Andrew Knox, one of Unilever's directors, argued that Unilever began to circulate staff in the 1960s, the following report on a UAC employee from Fredrick Pedler to Unilever's directors' committee suggests otherwise:

We have one most extraordinary character there - a Nigerian called Ojora who is 33 . He has been a director of UAC of Nigeria Limited for two years. He is the head of the Public Relations Department; he knows so much about some of our businesses and is so intelligent that he could give you very helpful advice as to marketing problems, financial problems, etc. He reckons to have a private talk with the Prime Minister every six weeks or so. . . He walks in and out of any other government office as he pleases and it is to be recognised that this man has immense power to do us good but, at the same time, the potential to do us harm if he were so minded. By virtue of his personality and 
performance he really does constitute a major management problem and one wonders what he is going to do with the rest of his life. ${ }^{83}$

In contrast to the instance of a promising European, promoting an African to a highlevel position at the head office in the United Kingdom, or circulating them internationally, was not considered. ${ }^{84}$ Polycentric strategies did not necessarily evolve into geocentric approaches, as argued by Perlmutter in 1969. Their relevance lay predominantly in legitimizing organizations during the postcolonial transition, a period of political, economic, and social change in formerly colonial countries.

For highly diversified multinationals that were present in more than one region (Unilever, Barclays), polycentric management posed less of a challenge in terms of transferring control to a domestic team (who were not promoted to the multinational head office). For regionally focused multinationals, a decentralized management style challenged their existing structure of U.K. head offices directing operations in Ghana and Nigeria. The three regional multinationals in this study were all acquired by larger, more diversified multinationals in the late 1960s: BWA became part of Standard Bank, while Holt and AGC were acquired in 1968 by Lonrho, the African multinational. ${ }^{85}$ Legitimacy was not just a metaphorical "license to operate," because AGC's mining license had been revoked by the Ghanaian government in 1969 because of Spears's intransigence, precipitating Lonrho's takeover. ${ }^{86}$ Even though Africanization is not the only element of polycentric management, without it multinationals could not have adapted to domestic political demands while retaining control over their subsidiaries. The acquisitions by more diversified multinationals such as Lonrho and Standard suggest that there were limits to how far regional multinationals could stretch in terms of polycentrism.

The fate of UAC is illustrative in this context. As a wholly owned subsidiary of Unilever, the company operated originally only in Africa, with a focus on West Africa. In the 1950s and 1960s it sought to diversify geographically, within and beyond Africa - a strategy that failed. By the 1970s it was heavily dependent on Nigeria for its profitability, and when oil prices collapsed in the 1980s so did UAC. It was absorbed into the Africa and Middle East Group with other regional investments. ${ }^{87}$ Part of the problem was UAC's very large U.K. head office, which was essentially a large purchasing office. ${ }^{88}$ While UAC had become polycentric in its approach, and cannot be considered as a regional multinational in the narrow sense, maintaining this head office without any independently profitable operations, there was a problematic legacy for a highly decentralized multinational. 
Conclusion

In this article, I have drawn on international business and organization theory to better explain the historical development of MNCs. By considering both older theories, such as those of Perlmutter, and contemporary approaches with an affinity to history, such as legitimacy, I have highlighted how business history can benefit from both. The case of British multinationals in Ghana and Nigeria shows how firms seek to repair organizational legitimacy in the long term by changing their structure and management. Perlmutter first observed significant changes to the way these multinationals were managed. The shift to polycentric management, most clearly seen in the trend to hire and promote local staff to replace expatriates, also had a direct impact on the likelihood of survival for certain types of firms. Polycentric management offered significant legitimacy advantages for multinationals operating in former colonies, which ultimately favored internationally diversified companies over regionally focused multinationals. While these insights are based on historical case studies of five companies, including three regional multinationals, future research might address whether these trends are representative of a larger population of firms.

Early attempts to make moral claims through improving employees' welfare were tailored toward colonial development concerns, which were unaligned with nationalist ideals of progress. By first pragmatically addressing the demands of the new audience of African stakeholders through Africanization, companies tried out a new approach. This was reinforced by experiences in other areas of the world with similar trends, especially in the case of the more geographically diversified multinationals. Increased Africanization normalized these practices both within the multinationals and as an expectation in their host countries. Polycentric management also devolved more decisions to the local level, but in a manner that was consistent with the way in which multinationals managed their subsidiaries. This allowed management to focus attention on external legitimacy concerns, specifically those germane to host countries, where value judgments were quite different from the expectations of their headquarters.

Nigeria and Ghana implemented expropriation decrees in the late 1960s and 1970s, taking the requirement for local content beyond staffing into the area of local ownership and control. ${ }^{89}$ However, their senior African managers were skilled at negotiating deals that retained more control for multinationals, such as share offerings or management contracts. 
Most of these decrees were reversed by the 1980s, as West African economies suffered deep economic shocks, but some sectors, including Nigerian finance and extractive industries, became domestically controlled. ${ }^{90}$ Biersteker argued that African managers stood to gain the most from the Nigerian expropriation decrees. ${ }^{91}$ Subsequent privatization and the removal of local content requirements in the 1980s suggest that Africanization had more long-term impact than expropriations.

Significant legitimacy challenges such as those that occur during postcolonial transitions require foreign multinationals to adapt to domestic expectations and hence subsidiary management. Perlmutter's typology of ethnocentric and polycentric management approaches encapsulates the complex and interlocking changes that occurred at subsidiary and headquarter levels, as well as within the network of subsidiaries. Polycentric management addressed a range of legitimacy challenges, particularly the change in audience, i.e., who evaluated whether organizational practices were acceptable. It also proved an effective solution in the face of expropriations and economic upheaval; for example, UAC's Ghanaian subsidiary was managed quite independently by David Andoh in the 1970s, as no remittances were possible, and no capital was transferred from the United Kingdom to Ghana as a result. ${ }^{92}$

Multinationals that adopted polycentric management adapted better to the legitimacy challenges inherent in postcolonial transitions. This study focuses on the organizational level, specifically how subsidiaries respond to legitimacy challenges in host countries over the long term. Geographically diversified multinationals were better able to adopt polycentric management approaches than the more ethnocentric regional multinationals, and they responded more effectively to pragmatic and cognitive legitimacy challenges. All three regional multinationals in this study had been acquired by internationally diversified multinationals by the late 1960s, suggesting that ethnocentric subsidiary management had become defunct.

Historical research addresses the long-term effects of losing legitimacy: organizational types that are not sufficiently adapted to the legitimacy requirements of changing institutional frameworks fail, leading to acquisition or restructuring. The decline of regional multinationals in West Africa is a case of failure of an organizational form. By employing management and organizational theory in conjunction with archival sources, business historical research can generalize more broadly about the factors that disadvantaged certain types of multinational organizations in this time period, specifically, the deep-seated ethnocentrism inherent in their management structure. 
STEPHANIE DECKER is Professor in Organization Studies and History and the Associate Director for Research at Aston Business School. Her research has been on the history of multinationals in West Africa as well as the use of historical methodology and archival research in business and management. She is co-editor for Business History, and has published her work in Business History Review, Business History, Organization, Journal of Management Studies and Academy of Management Review.

I gratefully acknowledge the helpful comments I received from the editor and the anonymous reviewers, as well as many colleagues over the years at seminars and conferences. This includes the conference on the „Nationality of the Company“ in Frankfurt, Germany, in 2017, the Association of Business Historians Annual Conference in Glasgow, Scotland, in 2017, the re:Work workshop on „Multinationals and the Organization of Work" in Berlin, Germany, in 2015, and the Business History Conference in Frankfurt, Germany, in 2014, where a previous version of this paper received the Halloran Prize in the History of Corporate Responsibility.

${ }^{1}$ Marcelo Bucheli and Ruth V. Aguilera, "Political Survival, Energy Policies, and Multinational Corporations: A Historical Study for Standard Oil of New Jersey in Colombia, Mexico, and Venezuela in the Twentieth Century," Management International Review 50, no. 3 (2011): 347-78; Shakila Yacob and Nicholas J. White, "The 'Unfinished Business' of Malaysia's Decolonisation: The Origins of the Guthrie 'Dawn Raid,"” Modern Asian Studies 44, no. 5 (2010): 919-60; Sarah E. Stockwell, The Business of Decolonization: British Business Strategies in the Gold Coast (Oxford, 2000).

2 Marcelo Bucheli and E. Salvaj, "Reputation and Political Legitimacy: ITT in Chile, 1927-1972," Business History Review 87, no. 4 (2013): 729-56.

${ }^{3}$ Marcelo Bucheli and Jin Uk Kim, "The State as a Historical Construct in Organization Studies," in Organizations in Time: History, Theory, Methods, ed. Marcelo Bucheli and R. Daniel Wadhwani (Oxford and New York, 2014), 256.

${ }^{4}$ Mark C. Suchman, "Managing Legitimacy: Strategic and Institutional Approaches," Academy of Management Review 20, no. 3 (1995): 574.

${ }^{5}$ Steve Maguire and Cynthia Hardy, "Discourse and Deinstitutionalisation: The Decline of DDT," Academy of Management Journal 52, no. 1 (2009): 148-78; Wesley D. Sine and Robert J. David, "Environmental Jolts, Institutional Change, and the Creation of Entrepreneurial Opportunity in the US Electric Power Industry," Research Policy 32, no. 2 (2003): 185-207.

${ }^{6}$ Geoffrey Jones, "Multinational Strategies and Developing Countries in Historical Perspective" (Harvard Business School Working Paper No. 10-076, Boston, 2010); Mark Casson and Teresa da Silva Lopes, "Foreign Direct Investment in High-Risk Environments: An Historical Perspective," Business History 55, no. 3 (2013): 375-404; Noel Maurer, The Empire Trap: The Rise and Fall of U.S. Intervention to Protect American Property Overseas, 1893-1976 (Princeton, 2013).

${ }^{7}$ Walter A. Friedman and Geoffrey Jones, "Business History: Time for Debate," Business History Review 85, no. 1 (2011): 2 . 
${ }^{8}$ For Africa, see: Andrew Cohen, "Lonrho and the Limits of Corporate Power in Africa, c. 1961-1973," South African Historical Journal 68, no. 1 (2016): 31-49; Stephanie Decker, "Corporate Political Activity in Less Developed Countries: The Volta River Project in Ghana, 1959-1966,” Business History 53, no. 7 (2011): $993-$ 1017; Ann Genova, "Nigeria's Nationalization of British Petroleum," The International Journal of African Historical Studies 43, no. 1 (2010): 115-36; Bianca Murillo, “"The Modern Shopping Experience': Kingsway Department Store and Consumer Politics in Ghana," Africa Today 82, no. 3 (2012): 368-92; Dmitri van den Bersselaar, “'Doorway to Success?': Reconstructing African Careers in European Business from Company House Magazines and Oral History Interviews," History in Africa 38 (2011): 257-94; Grietjie Verhoef, "Nationalism, Social Capital and Economic Empowerment: SANLAM and the Economic Upliftment of the Afrikaner People, 1918-1960," Business History 50, no. 6 (2008): 695-713. For Asia, see: Elisabeth Köll, From Cotton Mill to Business Empire: The Emergence of Regional Enterprises in Modern China (Cambridge, Mass., 2003); Andrew Smith, "The Winds of Change and the End of the Comprador System in the Hongkong and Shanghai Banking Corporation,” Business History 58, no. 2 (2016): 179-206; Yacob and White, “'Unfinished Business' of Malaysia's Decolonisation.” For the Middle East, see: Neveen Abdelrehim and Steve Toms, “The Obsolescing Bargain Model and Oil: The Anglo-Iranian Oil Company 1933-1951,” Business History 59, no. 4 (2017): 55471. For Latin America, see: Stephen Haber, Noel Maurer, and Armando Razo, "When the Law Does Not Matter: The Rise and Decline of the Mexican Oil Industry," Journal of Economic History 63, no. 1 (2003): 1-32; Marcelo Bucheli, "Major Trends in the Historiography of the Latin American Oil Industry," Business History Review 84, no. 2 (2010): 339-62; Rory Miller, “British Investment in Latin America, 1850-1950,” Itinerario 19, no. 3 (1995): 21-52.

${ }^{9}$ For example, Robin S. Gendron, Mats Ingulstad, and Espen Storli (eds.), Aluminum Ore: The Political Economy of the Global Bauxite Industry (Vancouver, 2013).

10 Jeffrey Pfeffer and Gerald R. Salancik, The External Control of Organizations: A Resource Dependence Perspective (New York, 1978).

${ }^{11}$ Suchman, "Managing Legitimacy," 574.

12 Ibid.

${ }^{13}$ Howard E. Aldrich and C. Marlene Fiol, "Fools Rush In? Tahe Institutional Context of Industry Creation," Academy of Management Review 19, no. 4 (1994): 645-70.

14 Suchman, "Managing Legitimacy," 578.

15 Ibid., 579.

${ }^{16}$ Ibid., 582.

${ }^{17}$ Bucheli and Kim, "State as a Historical Construct," 249.

${ }^{18}$ Stephanie Decker, "Postcolonial Transitions in Africa: Decolonization in West Africa and Present Day South Africa," Journal of Management Studies 47, no. 5 (2010): 791-813.

19 Marcelo Bucheli and Gonzalo R. Sommer, "Multinational Corporations, Property Rights, and Legitimization Strategies: US Investors in the Argentine and Peruvian Oil Industries in the Twentieth Century," Australian Economic History Review 54, no. 2 (2014): 145-63.

${ }^{20}$ Tatiana Kostova and Srilata Zaheer, "Organizational Legitimacy under Conditions of Complexity: The Case of the Multinational Enterprise," Academy of Management Review 24, no. 1 (1999): 64-81. 
${ }^{21}$ Alex Bitektine, "Toward a Theory of Social Judgments of Organizations: The Case of Legitimacy, Reputation, and Status,"Academy of Management Review 36, no. 1 (2011): 151-79.

22 Stephanie Decker, "The Silence of the Archives: Business History, Post-Colonialism and Archival Ethnography," Management \& Organizational History 8, no. 2 (2013): 155-73.

${ }^{23}$ Martha Howell and Walter Prevenier, From Reliable Sources: An Introduction to Historical Methods (Ithaca, 2001).

${ }^{24}$ Mira Wilkins, “The Free-Standing Company, 1870-1914: An Important Type of British Foreign Direct Investment," Economic History Review 41, no. 2 (1988): 259-82.

${ }^{25}$ Margaret Ackrill and Lesley Hannah, Barclays: The Business of Banking, 1690-1996 (Cambridge, U.K., 2001).

26 Gareth Austin, "Capitalists and Chiefs in the Cocoa Hold-Ups in South Asante, 1927-1938," International Journal of African Historical Studies 21, no. 1 (1988): 63-95; Jan-Georg Deutsch, Educating the Middlemen: Political and Economic History of Statutory Cocoa Marketing in Nigeria, 1936-1947 (Berlin, 1995).

${ }^{27}$ Mr. Rawlings to Mr. Goddard, District Agent Accra, 26 July 1844, Mss Afr. S.825, 232 (ii), Rhodes House, Oxford University (hereafter, RHO); "Kojo Thompson Is Said to Be Fighting the Case of All African Merchants," no newspaper name, n.d., Mss Afr. S.825, 232 (i), RHO; Deutsch, Educating the Middlemen, 25758.

${ }^{28}$ N.J. White, "Imperial Business Interests, Decolonization and Post-Colonial Diversification," in The Oxford Handbook of the Ends of Empire, ed. M. Thomas and A. Thompson (Oxford and New York, 2017).

29 F. Cooper, "From Free Labor to Family Allowances: Labor and African Society in Colonial Discourse," American Ethnologist 16, no. 4 (1989): 745-65.

${ }^{30}$ Colonial Office, "Social Welfare in the Colonies” (Apr. 1945, rev. Jan. 1948); Colonial Office, Social Development in the British Colonial Territories: Report on the Ashridge Conference on Social Development, 312 Aug. 1954 (Misc. No. 523), 44, appendix C.

${ }^{31}$ Colonial Office, "Social Welfare in the Colonies," 44.

${ }^{32}$ F. Cooper, Decolonization and African Society (Cambridge, U.K., 1996), 206.

${ }^{33}$ G. Cotgreave, District Agent Lagos, to Gates, Liverpool, 9 Nov. 1949, Mss Afr. s 825, 232 (ii), RHO.

${ }^{34}$ Frederick J. Pedler, Business and Decolonization in West Africa, c.1940-1960 (Oxford, 1989), 9.

35 Stockwell, Business of Decolonization.

${ }^{36}$ Chibuike Uche, "Lonrho in Africa: The Unacceptable Face of Capitalism or the Ugly Face of NeoColonialism?” Enterprise \& Society 16, no.2 (2015): 354-380.

${ }^{37}$ Stephanie Decker, "Less Than an Empire and More Than British: Foreign Investor Competition in Ghana and Nigeria in the 1960s," in Imagining Britain's Economic Future, c.1800-1975: Trade, Consumerism and Global Markets, ed. David Thackeray, Andrew Thompson, and Richard Toye (London, 2018), $183-203$.

38 Raymond E. Dumett, "The Gold Mining Centres of Tarkwa and Obuasi, Ghana: Colonial Administration and Social Change at Company Towns in an African Setting," in Sozialgeschichte des Bergbaus im 19. und 20. Jahrhundert, ed. Klaus Tenfelde (Munich, 1992), 850-51.

${ }^{39}$ I.G. Jones, "Labour Conditions in Obuasi," 1942, CSO 21/8/48, Public Records Administration and Archives Department, Accra, Ghana (hereafter, PRAAD); Stockwell, Business of Decolonization, 177. 
${ }^{40}$ I.G. Jones, “Report by the Labour Officer,” Mar. 1945, AGC Ms 14,171, v.97, Jan.-June 1945, London Metropolitan Archives (hereafter, LMA).

${ }^{41}$ J. Maltby and M. Tsamenyi, "Narrative Accounting Disclosure: Its Role in the Gold Mining Industry on the Gold Coast 1900-1949," Critical Perspectives on Accounting 21, no. 5 (2010): 390-401.

${ }^{42}$ Minutes of conference, 30 Nov. 1945, 4, AGC Ms 14,171, v. 98, July-Dec. 1945, LMA.

${ }^{43}$ Cooper, Decolonization and African Society, 3, 19, 470.

${ }^{44}$ Cooper, "Free Labor to Family Allowances," 758-59.

45 Directors' Committee, 32 The Gold Coast, 21.1.50, UNI/BD/DC, Unilever Historical Archives, Port Sunlight (hereafter, UHA).

46 "Announcement by the Leader of Government Business in the Assembly," 24 Apr. 1951, Mss Afr. s $825,421(\mathrm{v})$, RHO.

${ }^{47}$ Cable from General Manager Accra, UAC, 21 Apr. 1951; Previous paragraph: Cable from General Manager Accra, UAC, 20 Apr. 1951; Cable to General Manager Accra, UAC, 20 Apr. 1951, all Mss Afr. s 825, 421 (v), RHO.

${ }^{48}$ Cooper, Decolonization and African Society, 468.

${ }^{49}$ Stockwell, Business of Decolonization.

50 Thomas L. Hodgkin, Nationalism in Colonial Africa (London, 1956), 115.

51526 Parl. Deb. H.C. (5th ser.) (1954) cols. 1623-28; Martin Lynn, "We Cannot Let the North Down: British Policy and Nigeria in the 1950s," in The British Empire in the 1950s: Retreat or Revival?, ed. M. Lynn (Basingstoke, 2006), 144-63.

${ }^{52}$ Colonial Office, Nigeria: Report for the Year 1948 (London, 1949), 3.

${ }^{53}$ Pedler, Business and Decolonization, 8.

54 Richard Rathbone, "Parties' Socio-Economic Bases and Regional Differentiation in the Rate of Change in Ghana," in Transfer and Transformation: Political Institutions in the New Commonwealth. Essays in Honour of W.H. Morris-Jones, ed. P. Lyon and J. Manor (Leicester, 1983), 143-56.

${ }^{55}$ HowardV. Perlmutter, "The Tortuous Evolution of the Multinational Corporation," Columbia Journal of World Business 4, no. 1 (1969): 9.

${ }^{56}$ W. Harragin, Report of the Commission on the Civil Services of British West Africa, 1945-46 (London, 1947), 10; Colonial Office, Nigeria: 1948, 127.

${ }^{57}$ D.J. Morgan, The Official History of Colonial Development: Guidance towards Self Government in British Colonies, 1941-1971 (London, 1980), 327.

58 See also van den Bersselaar, "Doorway to Success?," 284.

${ }^{59}$ R.G. Dyson, “Mr. Dyson's West Africa Tour, 1952,” 15 Feb.-25 Mar. 1952, 39, 80/4328, Barclays Group Archives, Manchester (hereafter, BGA).

${ }^{60}$ Colonial Office, Nigeria: Report for the Year 1953 (London, 1953), 5-6.

${ }^{61}$ Colonial Office, Nigeria: Report for the Year 1950 (London, 1950), 53.

${ }^{62}$ Commission on Post-School Certificate and Higher Education in Nigeria, Investment in Education: The Report of the Commission on Post-School Certificate and Higher Education in Nigeria (Lagos, 1960), 7, 64, 90; Dyson, "Mr. Dyson's West Africa Tour." 
${ }^{63}$ Richard Jolly, Planning Education for African Development: Economic and Manpower Perspectives (Nairobi, 1969), 104; Frederick Cooper, Africa since 1940: The Past of the Present (Cambridge, U.K., 2002$), 114$.

${ }^{64}$ Harragin, Report of the Commission, 8.

${ }^{65}$ Commission, Investment in Education, 5, 18.

66 J.B. Loynes, "Nigeria," 26 Feb. 1958, 1-2, OV 68/5, Bank of England Archive, London (hereafter $\mathrm{BoE})$.

${ }^{67}$ G.A. Onagoruwa to General Manager (Staff), Feb./Mar. 1948, 38/906, BGA.

68 See, for example, UAC, Statistical and Economic Review, 25 (London, 1961), 62; Dyson, "Mr. Dyson's West Africa Tour”; W.W. Milne, “African Staff,” 12 June 1946, 38/9061, BGA; G. A. Onagoruwa to General Manager (Staff), n.d., 80/5044, BGA.

${ }^{69}$ Frederick Seebohm, "Diary,” Ghana, 31 Jan.-9 Feb. 1954, n.p., 277/1, BGA; see also M. Burawoy, The Colour of Class (Manchester, 1972), 37.

${ }^{70}$ Manager John Holt to all District Agents, “African Managerial Staff,” 10 Dec. 1948, in Josephine F. Milburn, British Business and Ghanaian Independence (London, 1977), 74.

${ }^{71}$ Nigeria, Federal House of Representatives, House of Representatives Debates, 29 Nov. 1961, cols. 3542, 3573, exchange between Chief Festus and Mr. W.O. Briggs.

72 Ibid.

${ }^{73}$ E. Spears, 31 Mar. 1965, “Ashanti Goldfields Corporation,” AGC Ms24661, LMA. See also African senior executive manager of Barclays Bank Ghana, interview with author, Accra, 6 July 2004.

${ }^{74}$ Minutes of Heads of Departments, 22 Apr. 1966, AGC Ms 14,171 v. 164, Jan.-June 1966, LMA; Ag. General Mines Manager to Secretary, 12 Sep. 1961, Ms 24,663, v. 1 July-Dec. 1961, LMA; Minutes of Heads of Departments meeting, 15 Feb. 1963, Ms 24,663, v. 4 Jan.-June 1963, LMA.

75 Dyson, “Mr. Dyson's West African Tour,” 15 Feb.-25 Mar. 1952, 36, 39; “List of Senior Staff Nigeria," 80/4328, BGA; R.E. Fleming and E.V. Whitcombe, "Visit to Nigeria and the Cameroons," July 1960, 80/3466, BGA; Barclays to J. Milburn, July 1966, in Milburn, British Business and Ghanaian Independence, 85.

${ }^{76}$ UAC, Statistical and Economic Review, 25 (London, 1961), 62.; Col. Westmorland to E.W. Morgan, 8 Mar. 1963 [dated 8 Apr. 1963 in error], AGC Ms 24, 665, LMA; Hamilton, “Intelligence Report,” No. 412, n.d., AGC Ms 14,171, v. 122, July-Dec. 1955, LMA; Eme O. Awa, Federal Government in Nigeria (Berkeley, CA, 1964), 173.

77 “Ghana Board Members,” 80/3580, BGA; J. Wathen to G.N.M. Law, 29 Sept. 1961, 80/3580, BGA; Memorandum “CAST” to General Manager, 30 June 1960, 80/3580, BGA; Boreham to J. Crossley, 3 Jan. 1961, 80/3580, BGA; Wathen to Crossley, 20 Jan. 1964, 80/3580, BGA; Wathen's reminiscences, BGA 1189/1; Trevor Jones, Ghana's First Republic 1960-1966 (New York, 1977), 54.

${ }^{78}$ D.L.G. Davies to G.N.M. Law, 16 June 1961, 80/4448, BGA; F.A. Boreham, “Mr. Boreham's Visit to Nigeria," 3-19 July 1961, 2, 80/4448, BGA.

${ }^{79}$ Richard Fry, Bankers in West Africa: The Story of the Bank of British West Africa Limited (London, 1976), 190, 256.

80 "Draft: Africanisation - Recruitment, Training and Development," n.d., UAC1/9/1/5/5, UHA.

81 “The Impact of Africanisation on U.A. Group Activities," n.d., UAC 1/9/1/5/5, UHA.

${ }^{82}$ A.M. Knox, Coming Clear (London, 1976), 167.

${ }^{83}$ F.J. Pedler, Report to Directors' Conference, UNI/SC with TAC, 10 Dec. 1965, UHA. 
${ }^{84}$ See Knox, Coming Clear, 169-70. Senior executive manager of Barclays Bank of Ghana, interview with author, 6 July 2004.

${ }^{85}$ Uche, "Lonrho in Africa"; Cohen, "Lonrho and the Limits."

86 Ayowa Afrifa Taylor, "An Economic History of the Ashanti Goldfields Corporation, 1895-2004" (PhD diss., London School of Economics and Political Science, 2006).

${ }^{87}$ D Avid K. Fieldhouse, Merchant Capital and Economic Decolonisation (Oxford, 1994).

${ }^{88}$ Roy Barlow, former UAC employee (sailor, head office), interview with the author, 20 Oct. 2005, Liverpool.

${ }^{89}$ Gareth Austin, “African Business History," in Routledge Companion to Business History, ed. John Wilson (Basingstoke, 2016), 141-58.

${ }^{90}$ Genova, "Nigeria's Nationalization”; Thomas J. Biersteker, Multinationals, the State, and Control of the Nigerian Economy (Princeton, 1987).

${ }^{91}$ Biersteker, Multinationals, 281, 244.

92 Clark to Marriott, 9 May 1975; Watt to Clark, 17 July 1975; Clark to Louden, 31 July 1975, all 1/2/2/7/9, UHA. 